\title{
Selenium Improves Physiological Parameters and Alleviates Oxidative Stress in Shoots of Lead-Exposed Vicia faba L. minor Plants Grown Under Phosphorus-Deficient Conditions
}

\author{
Magdalena Mroczek-Zdyrska $^{1} \cdot$ Joanna Strubińska $^{1} \cdot$ Agnieszka Hanaka $^{2}$
}

Received: 26 January 2016/Accepted: 13 July 2016/Published online: 15 September 2016

(c) The Author(s) 2016. This article is published with open access at Springerlink.com

\begin{abstract}
The goal of the study was to investigate the effects of exogenous selenium (Se) on the tolerance of faba bean plants to lead $(\mathrm{Pb})$ stress under P-deficient conditions. The bean plants were grown for 2 weeks on Hoagland solution supplied with $\mathrm{Pb}(0,50 \mu \mathrm{M})$ and $\mathrm{Se}(0,1.5$, or $6 \mu \mathrm{M})$, separately or simultaneously. It was shown that $\mathrm{Pb}$ did not affect shoot growth but caused major damage in the leaves, which was accompanied by $\mathrm{Pb}$ accumulation in these tissues. The exposure of the shoots to $\mathrm{Pb}$ led to significant changes in the biochemical parameters: the MDA content, glutathione peroxidase (GSH-Px), guaiacol peroxidase (GPOX), and catalase (CAT) activity increased. Furthermore, $\mathrm{Pb}$ intensified $\mathrm{O}_{2}^{\bullet-}$ and $\mathrm{H}_{2} \mathrm{O}_{2}$ production. Both the $\mathrm{Se}$ concentrations used increased the chlorophyll $b$, chlorophyll $a+b$, and carotenoid content in the faba bean plants. Selenite also generally enhanced CAT, GPOX, and GSH-Px activities and the T-SH level. Our results imply that the degree of disturbances caused by $\mathrm{Pb}$ could be partially ameliorated by Se supplementation. Selenite at a lower dose alleviated $\mathrm{Pb}$ toxicity by decreased $\mathrm{H}_{2} \mathrm{O}_{2}$ and $\mathrm{O}_{2}^{\bullet-}$ production and decreased the GSH-Px, GPOX, and CAT activities. The beneficial effect of the higher selenite concentration could be related to reduction of lipid peroxidation in the shoots of the $\mathrm{Pb}$-treated plants. However, the effect of $\mathrm{Se}$ on the $\mathrm{Pb}$-stressed plants greatly depended on the selenite dose in the nutrient solution.
\end{abstract}

Magdalena Mroczek-Zdyrska

mroczek.mag@gmail.com;

magdalena.mroczek@poczta.umcs.lublin.pl

1 Department of Cell Biology, Maria Curie-Sklodowska University, Akademicka 19, 20-033 Lublin, Poland

2 Department of Plant Physiology, Maria Curie-Sklodowska University, Akademicka 19, 20-033 Lublin, Poland
Keywords Antioxidant enzymes - Oxidative stress · Growth · Lead · Selenium - Vicia faba L. minor

\section{Introduction}

Plants are able to absorb and accumulate diverse types of metals, from toxic to those with unknown metabolic functions. Heavy metals present in the environment in excess are dangerous for human and animal health. Lead $(\mathrm{Pb})$ belongs to the most common and dangerous heavy metals. $\mathrm{Pb}$ binds strongly to sulfhydryl groups of proteins and contributes to distortion of enzymes and structural proteins. $\mathrm{Pb}$ accumulation in plant tissues results in numerous disturbances of physiological processes such as alterations in cell membrane permeability, water stress, disturbances in cell division, or inhibition of the electron transport during photosynthesis and respiration (Sengar and others 2008). One of the visible symptoms of $\mathrm{Pb}$ toxicity in plants is growth inhibition or leaf chlorosis (Garg and Aggarwal 2011; Sengar and others 2008). Pb induces oxidative stress and ROS production in plant tissues. To overcome the effect of $\mathrm{Pb}$ stress, plants can effectively scavenge oxygen species: $\mathrm{H}_{2} \mathrm{O}_{2},{ }^{\bullet} \mathrm{OH}$, and $\mathrm{O}_{2}^{\bullet-}$. Both enzymatic (catalases and peroxidases) and non-enzymatic antioxidants (GSH, AsA, and car) are involved in this process (Verma and Dubey 2003).

Recent studies have reported that Central Italy, France, Germany, and the UK show relatively high, but still within guidelines, concentrations of $\mathrm{Pb}$ in agricultural soils. However, the widespread occurrence of $\mathrm{Pb}$ in soils indicates the need for strict control of $\mathrm{Pb}$ in agricultural land and in the food chain. Lazio, a province in Central Italy, is considered as the most $\mathrm{Pb}$-contaminated region due to volcanic materials (Tóth and others 2016). 
Research attention has been focused on identifying factors that could contribute to reduction of $\mathrm{Pb}$ absorption or toxicity in plant organisms. Selenium (Se) is one of the potential antagonists of $\mathrm{Pb}$. Many studies in animals have confirmed the antagonistic effect of $\mathrm{Se}$ on $\mathrm{Hg}, \mathrm{Cd}, \mathrm{Zn}, \mathrm{Cu}$, or Ag toxicity (Cabañero and others 2006). For this reason, research on enrichment of crop plants (mustard, onions, garlic, cereal) with Se and their use as an effective source of Se in the human diet are very popular (Guo and others 2014)

The role of Se in plants is not well known and is still controversial. Se is not an essential element for higher plants. However, plants take up and metabolize Se in tissues. Se accumulation differs among plant species. Depending on the amount of accumulated Se, plants have been classified as "non-Se-accumulators" (grasses and most forage and crop plant species), which usually contain less than $25 \mathrm{mg} \mathrm{Se} \mathrm{kg}{ }^{-1} \mathrm{DW}$, "Se-hyperaccumulators" having the ability to take up hundreds to several thousand $\mathrm{mg}$ of Se $\mathrm{kg}^{-1} \mathrm{DW}$, and "Se-indicators" accumulating up to $1000 \mathrm{mg} \mathrm{Se} \mathrm{kg}^{-1} \mathrm{DW}$. Moreover, the boundary between the tolerated and toxic dose of $\mathrm{Se}$ is narrow. High $\mathrm{Se}$ concentrations are toxic to plants. Se toxicity results from its incorporation into amino acids to substitute sulphur and formation of Se-amino acids. Next, Se-amino acids are incorporated into protein and $\mathrm{S}-\mathrm{S}$ bonds are replaced by the less stable $\mathrm{Se}-\mathrm{Se}$ bonds. This is a reason for the modification in the biological activity of the protein (Terry and others 2000). The influence of Se on plants depends both on its chemical form and its concentration in the nutrient solution. Although there is no evidence for Se requirement in non-accumulator plants, numerous studies report that at low concentrations Se exerts a beneficial effect on antioxidant properties, alleviating oxidative stress and promoting plant growth and development (Cartes and others 2005; Djanaguiraman and others 2005; Hartikainen and others 2000; Terry and others 2000; Xue and others 2001). The selenate and selenite doses routinely used under hydroponic conditions to counteract environmental stress are often less than $1 \mathrm{mg} \mathrm{L}^{-1}$ (Feng and others 2013a). Hartikainen and others (2000) showed that selenate at low concentrations behaved as an antioxidant, whereas at higher concentrations it acted as a prooxidant. A low dose of $\mathrm{Se}$ in the form of selenite was also associated with a $43 \%$ increase in seed production in Brassica rapa $\mathrm{L}$. (Lyons and others 2009). Recent research indicates that addition of Se may protect plants against salt stress (Kong and others 2005), drought (Wang and others 2011), and UV-irradiation (Hartikainen and Xue 2000). Moreover, the still growing number of publications shows that addition of Se may also affect the total content of heavy metals by decreasing their uptake by plants (He and others 2004; Fargašová and others 2006; Feng and others 2013b;
Mroczek-Zdyrska and Wójcik 2012). Several studies have indicated that Se can affect plant tolerance to toxic metals due to not only inhibition of heavy metal uptake and alleviation of oxidative stress but also, because of chloroplasts rebuilding, augmentation of the assimilation pigment and maintenance of cell membrane integrity (Feng and others 2013b).

However, to our knowledge, $\mathrm{Pb}$ and $\mathrm{Se}$ interactions in plants are still not clear and have been described by only a few authors (Fargašová and others 2006; Mroczek-Zdyrska and Wójcik 2012).

The faba bean (Vicia faba L.) is considered one of the oldest leguminous crops in the world. Globally, it is the third most important feed grain legume after soybean (Glycine max) and pea (Pisum sativum L) (Singh and others 2012). Its highly nutritional seeds are a crucial source of proteins and carbohydrates in food used for human consumption. According to the agricultural requirements, the main fields of interest in faba bean cultivation are yield improvement, disease resistance, abiotic stress tolerance, or seed quality (Gnanasambandam and others 2012).

Addition of phosphate to a $\mathrm{Pb}$-containing growth solution reduced the bioavailability of $\mathrm{Pb}$ (Zhang and Ryan 1999). Hence, to prevent precipitation of lead phosphate in the growth solution, we conducted the experiment in P-deficient conditions. We based this on the finding that plants can subsist on the reserves of $P$ stores in the seed for about two (Grant and others 2001) or even several weeks (White and Veneklaas 2012). Moreover, the uptake of Se by plant roots is also influenced by competing anions, such as sulphate and phosphate (Sors and others 2005). Selenite uptake is enhanced by low $\mathrm{S}$ and $\mathrm{P}$ concentrations or their absence (Winkel and others 2015). Li and others (2008) showed that $\mathrm{P}$ starvation resulted in a $60 \%$ increase in selenite uptake by wheat, possibly because $P$ starvation upregulated the expression of the phosphate transporter genes. Thus, the aim of the present study was to investigate the effect of $\mathrm{Pb}$ in combination with $\mathrm{Se}$ in P-deficient conditions on Vicia faba L. minor shoot growth and viability and on selected biochemical parameters (MDA and T-SH content) and antioxidant enzyme activity (CAT, GPOX and GSH-Px). Moreover, the ability of Se to alleviate $\mathrm{Pb}$ toxicity in Vicia faba L. minor shoots was tested and discussed.

\section{Materials and Methods}

\section{Plant Material and Experimental Design}

Vicia faba L. minor (cv. Nadwislanski) plants were grown hydroponically in a laboratory condition. Seeds were 
germinated on moist filter paper in plastic containers containing half-strength Hoagland's nutrient solution (with $\mathrm{NH}_{4} \mathrm{H}_{2} \mathrm{PO}_{4}$ to protect the plants from the short-term fluctuations in $\mathrm{P}$ supply) in the dark at $25{ }^{\circ} \mathrm{C}$ for 7 days. Then, the seedlings were transplanted into $3 \mathrm{~L}$ plastic containers (ten plants per one container) with modified full-strength Hoagland's medium (Hoagland and Arnon 1959) containing the following mineral components $(\mathrm{POCH}): \mathrm{KNO}_{3}(6 \mathrm{mM})$, $\mathrm{Ca}\left(\mathrm{NO}_{3}\right)_{2} \times 4 \mathrm{H}_{2} \mathrm{O}(4 \mathrm{mM}), \mathrm{MgSO}_{4} \times 7 \mathrm{H}_{2} \mathrm{O}(2 \mathrm{mM})$, iron citrate $(0.85 \mu \mathrm{M}), \quad \mathrm{H}_{3} \mathrm{BO}_{3}(46 \mu \mathrm{M}), \quad \mathrm{MnCl}_{2} \times 4 \mathrm{H}_{2} \mathrm{O}$ $(9 \mu \mathrm{M}), \quad \mathrm{ZnSO}_{4} \times 7 \mathrm{H}_{2} \mathrm{O} \quad(0.76 \mu \mathrm{M}), \quad \mathrm{CuSO}_{4} \times 5 \mathrm{H}_{2} \mathrm{O}$ $(0.32 \mu \mathrm{M})$, and $\mathrm{H}_{2} \mathrm{MoO}_{4} \times 2 \mathrm{H}_{2} \mathrm{O}(0.11 \mu \mathrm{M})$. To prevent precipitation of lead phosphate in growth solution (Zhang and Ryan 1999), $\mathrm{NH}_{4} \mathrm{H}_{2} \mathrm{PO}_{4}$ was removed from the Hoagland's solution in all experimental groups (Wierzbicka and Potocka 2002). Next, the experiment was conducted in $P$ deficiency conditions for 14 days. To determine the effect of $\mathrm{Pb}$ and $\mathrm{Se}$, the growth solution was supplemented with $50 \mu \mathrm{M} \mathrm{Pb}$ in the form of $\mathrm{Pb}\left(\mathrm{NO}_{3}\right)_{2}$ (lead nitrate, Sigma) and/ or 1.5 or $6 \mu \mathrm{M} \mathrm{Se}$ in the form of $\mathrm{Na}_{2} \mathrm{SeO}_{3}$ (sodium selenite, Sigma). We have chosen selenite, which is still not well explored, as a source of Se because both selenite (Terry and others 2000) and $\mathrm{Pb}$ (Garg and Aggarwal 2011) are mainly accumulated in the roots and their translocation to shoots is limited. We wanted to check whether selenite can be an effective factor in mitigation of $\mathrm{Pb}$ phytotoxicity. The $\mathrm{Pb}$ and Se concentrations were chosen on the basis of preliminary experiments and literature data. The 2-week cultivation was performed at $25 / 20{ }^{\circ} \mathrm{C}$ (day/night) under a $16 / 8 \mathrm{~h}$ (day/ night) photoperiod at photosynthetic active radiation of $150 \mu \mathrm{mol} \mathrm{m} \mathrm{m}^{-2} \mathrm{~s}^{-1}$. During the experiment, the nutrient solution was continuously aerated and its losses were supplemented daily with $\mathrm{dH}_{2} \mathrm{O}$. The solution was changed once a week and its $\mathrm{pH}$ was kept at 5.0-5.2.

The analyses were performed on plant shoots, fresh or frozen in liquid nitrogen, 14 days after addition of $\mathrm{Pb}$ and/ or Se. Five plants were selected from each plastic container for the respective analyses and all the measurements were performed in triplicate $(n=15)$. For the analysis of dry weight, the shoots were dried at $70{ }^{\circ} \mathrm{C}$.

\section{Determination of $\mathrm{Pb}$ and Se Content}

The shoot samples $(0.25 \mathrm{~g} \mathrm{DW})$ were mineralized in $10 \mathrm{ml}$ $\mathrm{HNO}_{3}$ using the microwave digestion system "MARS 5" (Varian). After digestion, the residues were diluted to $25 \mathrm{ml}$ with Milli-Q water. $\mathrm{Pb}$ and Se contents were determined by the method of atomic absorption spectrometry (AAS) with acetylene flame atomization in the air (FAAS) with the SPEKTR AA spectrometer (Varian). Se content was determined by the method of AAS with hydride generation (AAS-HG). Calibration curves for $\mathrm{Pb}$ and Se were done with certified calibration standards (Merck). Analysis of Se content was verified by certified reference material Standard Reference Material ${ }^{\circledR} 2709$ San Joaquin Soil. Reference material test precision for Se was $2.1 \%$.

\section{Histochemical Visualization}

Histochemical visualization was determined on the 1 st and 2nd pairs of leaves on day 14 of the experiment. Prior to staining, the leaves were washed under tap water and then rinsed three times in $\mathrm{dH}_{2} \mathrm{O}$. After staining, to obtain clear results, the leaves were washed in $\mathrm{dH}_{2} \mathrm{O}$ and chlorophyll was removed by boiling in $\mathrm{MeOH}(\mathrm{POCH})$ at $70^{\circ} \mathrm{C}$ in a water bath (Memmert).

Detection of $\mathrm{Pb}$ in plant shoots was performed using the rhodizonic method. After rinsing in $\mathrm{dH}_{2} \mathrm{O}$, the leaves were transferred to a $0.2 \%$ aqueous solution of the reagent containing 1 drop of Tween 20, evacuated three times in a vacuum pump for $10 \mathrm{~min}$, and left for $12 \mathrm{~h}$ in the dark. $\mathrm{Pb}$ was detected as dark-brown product formed with rhodizonic acid disodium salt (Sigma) (Wierzbicka 1987).

Assessment of leaf viability was performed by trypan blue staining. For this purpose, the leaves were placed in a boiling solution of the dye for $1 \mathrm{~min}$. Trypan blue (Sigma) cannot pass through intact membranes of living cells, whereas it easily penetrates the damaged cell membrane staining sites of necrosis (Belenghi and others 2003).

Detection of $\mathrm{H}_{2} \mathrm{O}_{2}$ in the leaves was carried out after the leaves were stained in a solution containing 3,3-diaminobenzidine (DAB, $0.1 \%, \mathrm{pH} 3.8$ ) (Sigma). The leaves were placed in a dye solution, then evacuated three times in a vacuum pump for $10 \mathrm{~min}$ and left for $12 \mathrm{~h}$ in the dark (Shinogi and others 2003).

Localization of $\mathrm{O}_{2}^{--}$in the leaves was carried out using NBT (Sigma) $(0.05 \%)$ in phosphate buffer $(0.05 \mathrm{M}, \mathrm{pH} 7.5)$ (Shinogi and others 2003). The leaves were placed in a solution of the dye, evacuated three times in a vacuum pump for $10 \mathrm{~min}$, and incubated in the dye for $1 \mathrm{~h}$. NBT led the reaction with $\mathrm{O}_{2}^{\circ-}$ forming oxidized NBT, a dark blue insoluble formazan.

\section{Chlorophyll and Carotenoid Determination}

The contents of chl $a$, chl $b$, and car were determined as described by Lichtenthaler and Wellburn (1983). Fresh leaves $(0.5 \mathrm{~g})$ were homogenized in $5 \mathrm{ml}$ of acetone (POCH) $\left(80 \%\right.$, chilled to $\left.4{ }^{\circ} \mathrm{C}\right)$. The homogenate was filtered and the precipitate was washed with cold acetone until the total chlorophyll extraction. Next, the extract was supplemented with $80 \%$ chilled acetone to $25 \mathrm{ml}$. The mixture was centrifuged (MPW-350R) at $10,000 \times g$ at $4{ }^{\circ} \mathrm{C}$ for $10 \mathrm{~min}$. The absorbance of the supernatant was measured at $663 \mathrm{~nm}(\operatorname{chl} a), 645 \mathrm{~nm}(\operatorname{chl} b), 652 \mathrm{~nm}(\operatorname{chl} a+b)$, and $470 \mathrm{~nm}$ (car) on a spectrophotometer (UV-VIS Helios Gamma). 


\section{Lipid Peroxidation Determination}

The level of lipid peroxidation was estimated as the content of MDA (Heath and Packer 1968). Frozen shoots (0.5 g) were homogenized in $5 \mathrm{ml}$ of $0.5 \%$ TBA (Sigma) in $20 \%$ TCA (Sigma) with $250 \mu$ BHT (Sigma). After heating at $95{ }^{\circ} \mathrm{C}$ for $30 \mathrm{~min}$, the mixture was quickly cooled in an ice bath and again centrifuged at $15,000 \times g$ for $15 \mathrm{~min}$. The absorbance of the supernatant was read at 532 and $600 \mathrm{~nm}$, the latter for unspecific turbidity which was subtracted. The MDA content was calculated with the extinction coefficient $\left(155 \mathrm{mmol}^{-1} \mathrm{~cm}^{-1}\right)$.

\section{Total SH Content Determination}

The total content of SH groups was determined as described by Maas and others (1987) with Ellman's reagent (DTNB) (Sigma). The frozen samples of shoots were homogenized in a cooled mortar in an extraction solution containing $0.15 \%$ ascorbic acid (Sigma), $2 \%$ SSA (Sigma), and $0.037 \% \mathrm{Na}_{2}$ EDTA (Sigma) $(5: 1, \mathrm{v} / \mathrm{w})$. The homogenate was centrifuged twice at $10,000 \times g$ for $15 \mathrm{~min}$ at $4{ }^{\circ} \mathrm{C}$. Supernatant $(0.5 \mathrm{ml})$ was mixed with $0.5 \mathrm{ml} 1 \mathrm{M}$ $\mathrm{K}_{2} \mathrm{HPO}_{4}-\mathrm{KH}_{2} \mathrm{PO}_{4}$ buffer (POCH) at $\mathrm{pH} 8.0$ and $0.1 \mathrm{ml}$ of $10 \mathrm{mM}$ DTNB (Sigma). The absorbance was measured at $\lambda=412 \mathrm{~nm}$ after 1 min with a UV-VIS spectrophotometer (Helios Gamma). The SH group content was read from the standard curve for L-cysteine (Sigma).

\section{Protein and Enzymatic Antioxidant Determinations}

Proteins were assayed according to Bradford (1976) using BSA (Sigma) as a standard with a UV-VIS spectrophotometer (Helios Gamma) 15 min after addition of colour dye (Bio-Rad Protein Assay) at $\lambda=595 \pm 10 \mathrm{~nm}$. The enzymatic assays were performed after the enzymes were extracted in $5 \mathrm{ml}$ (CAT and GPOX) or $2.5 \mathrm{ml}$ (GSH-Px) (Sigma) of $50 \mathrm{mM}$ phosphate buffer $(\mathrm{pH} 7.0)$ containing $1 \mathrm{mM}$ EDTA (Sigma) and $1 \%$ PVPP (Sigma). The homogenate was centrifuged twice at $10,000 \times g$ at $4{ }^{\circ} \mathrm{C}$ for $15 \mathrm{~min}$ and the supernatant was applied for the assays.

Determination of CAT (E.C. 1.11.1.6) activity was conducted in fresh plant samples $(1 \mathrm{~g})$ as described by Aebi (1984). Phosphate buffer (1.5 ml of $50 \mathrm{mM}, \mathrm{pH} 7.0)$ and $0.5 \mathrm{ml}$ of $0.15 \% \mathrm{H}_{2} \mathrm{O}_{2}$ (30 wt $\%$, Sigma) were added to the quartz cuvette. The reaction was initiated by adding $5 \mu \mathrm{l}$ of the supernatant to the reaction mixture at $25^{\circ} \mathrm{C}$. The absorbance decrease ( $\Delta$ Abs/min) was read at $\lambda=240 \mathrm{~nm}$ for $30 \mathrm{~s}$ with the UV-VIS spectrophotometer (Helios Gamma). The calculation includes the molar absorption coefficient of $\mathrm{H}_{2} \mathrm{O}_{2}\left(\varepsilon=0.036 \mathrm{mM}^{-1} \mathrm{~cm}^{-1}\right)$.

Measurement of GPOX (E.C. 1.11.1.7.) activity was determined in frozen plant samples $(0.5 \mathrm{~g})$ according to
Velikova and others (2000). The reaction mixture contained $2.75 \mathrm{ml}$ of $50 \mathrm{mM}$ phosphate buffer ( $\mathrm{pH} 7.0$ ) containing $1 \%$ guaiacol (Sigma) and $100 \mu \mathrm{l}$ of supernatant. The reaction was started by adding $150 \mu \mathrm{l} 100 \mathrm{mM} \mathrm{H}_{2} \mathrm{O}_{2}$ (30 wt $\%$, Sigma) to the reaction mixture and absorbance $(\Delta$ Abs/min) was read at $\lambda=470 \mathrm{~nm}$ after $30 \mathrm{~s}$ with a UVVIS spectrophotometer (Helios Gamma). The calculation includes the molar absorption coefficient of guaiacol $\left(\varepsilon=26.6 \mathrm{mM}^{-1} \mathrm{~cm}^{-1}\right)$.

GSH-Px (E.C. 1.11.1.9.) activity was determined in frozen plant samples $(0.5 \mathrm{~g})$ according to Ali and others (2006). The reaction mixture contained $50 \mathrm{mM}$ phosphate buffer $(\mathrm{pH} 7.0)$, $1 \mathrm{mM} \mathrm{Na} 2$ EDTA (Sigma), $0.25 \mathrm{U} \mathrm{ml}^{-1}$ GR (EC 1.6.4.2) (Sigma), $1 \mathrm{mM} \mathrm{L-GSH}$ (Sigma), $0.15 \mathrm{mM} \quad \beta-N A D P H$ (Sigma), $1 \mathrm{mM} \mathrm{NaN}_{3}$ (Sigma), and $20 \mu \mathrm{l}$ homogenate. The reaction was initiated by adding $1.5 \mathrm{mM}$ t-BOOH (Sigma) at $37{ }^{\circ} \mathrm{C}$ and the absorbance decrease was measured with a UVVIS spectrophotometer (Helios Gamma) at $\lambda=340 \mathrm{~nm}$. The reaction with t-BOOH allowed measurements of the activity of GSH-Px containing Se (without measuring the activity of GSHPx without Se). A unit of GSH-Px activity was the amount of the enzyme that catalyses oxidation of $\beta-\mathrm{NADPH}$ to $\beta-\mathrm{NADP}^{+}$ $\left(\mathrm{mM} \mathrm{min}{ }^{-1} \mathrm{mg}^{-1}\right.$ protein) at $25 \pm 2{ }^{\circ} \mathrm{C}$ with the molar absorption coefficient for the $\beta$-NADPH $\left(\varepsilon=6.22 \mathrm{mM}^{-1} \mathrm{~cm}^{-1}\right)$.

\section{Statistical Analysis}

To examine the biometric parameters, chlorophyll, and carotenoid contents, five plants were selected and all the measurements were performed in triplicate $(n=15)$. The biochemical analysis (the contents of MDA and T-SH, and the activities of CAT, GPOX, and GSH-Px) was performed in triplicate and all the experiments were run in three timeindependent repetitions $(n=9)$. Data are presented as the mean \pm standard errors (SE). Statistical analysis was carried out using one-way ANOVA and Tukey's post hoc analysis for determination interaction significance at $p<0.05$.

\section{Results}

\section{Se and $\mathrm{Pb}$ Accumulation and Plant Growth}

The $\mathrm{Pb}$ concentration in the plant shoots increased successively up to day 14 (data not shown), but finally, the shoots of Vicia faba L. minor accumulated only about $1.5 \%$ of the total $\mathrm{Pb}$ present in the plant. The addition of $\mathrm{Se}$ to the $\mathrm{Pb}$-treated plants did not alter $\mathrm{Pb}$ accumulation in the shoots. However, in the presence of both $\mathrm{Pb}$ and $6 \mu \mathrm{M}$ $\mathrm{Se}$, we noted a $34 \%$ decrease in the Se content in comparison to plants treated with $6 \mu \mathrm{M}$ Se only (Table 1). 
Elongation of the shoots in the Pb-treated plants was at the level of the control plants. The presence of Se without and with $\mathrm{Pb}$ stress had no effect on shoot growth, shoot elongation, FW and DW of the shoots, the number of leaves, and the length and width of leaves (Table 2).

\section{Measurements of Chlorophyll and Carotenoids}

A significant decrease ( $2 \%$ ) in the chl $a$ content was found only in the $1.5 \mu \mathrm{M}$ Se and $50 \mu \mathrm{M} \mathrm{Pb}+1.5 \mu \mathrm{M}$ Se-treated plants in comparison to the control. The content of these compounds in all groups increased in comparison to the control at least $20 \%(\mathrm{chl} b)$ and at least $10 \%(\mathrm{chl} a+b$ and car). The increase in the chl $b$ content was accompanied by a proportional decrease in the ratio $\mathrm{R}{ }^{a} b$ (Table 3 ).

\section{Histochemical Detection of $\mathbf{P b}$}

There were no $\mathrm{Pb}$ deposits in the leaves of the control and Setreated plants. The 14-day exposition of the plants to $\mathrm{Pb}$ resulted in distinct colouration of the leaves. On the 1st pair leaves, $\mathrm{Pb}$ deposits were observed along the main nerve, whereas on the 2 nd pair leaves, dark-brown colour occurred mainly at the top and the edges of the leaf blade. The addition of Se at the concentration of 1.5 and $6 \mu \mathrm{M}$ to the medium containing $\mathrm{Pb}$ decreased accumulation both in the 1 st and 2nd pairs of leaves. A more significant effect was found for Se at the concentration of $1.5 \mu \mathrm{M}$, which visibly decreased staining intensity in the 1 st pair leaves and almost completely reduced it in the 2 nd pairs of leaves (Fig. 1).

\section{Histochemical Detection of Viability}

The macroscopic observations showed varied and age-dependent viability of the control leaves. After 14 days, a slight blue colour appeared over the entire surface of the

Table 1 Lead and selenium contents in Vicia faba L. minor shoots grown for 14 days in the control solution or in the presence of $\mathrm{Pb}$ and/ or Se

\begin{tabular}{|c|c|c|}
\hline \multirow{2}{*}{$\begin{array}{l}\mathrm{Pb} \text { and/or Se } \\
\text { concentration }(\mu \mathrm{M})\end{array}$} & \multicolumn{2}{|c|}{$\left(\mathrm{mg} \mathrm{kg}^{-1} \mathrm{DW}\right)$} \\
\hline & $\mathrm{Pb}$ & $\mathrm{Se}$ \\
\hline 0 & ND & $0.42 \mathrm{a}$ \\
\hline $1.5 \mathrm{Se}$ & ND & $4.69 \mathrm{~b}$ \\
\hline $6 \mathrm{Se}$ & ND & $4.67 \mathrm{~b}$ \\
\hline $50 \mathrm{~Pb}$ & $168 \mathrm{a}$ & $0.41 \mathrm{a}$ \\
\hline $50 \mathrm{~Pb}+1.5 \mathrm{Se}$ & $153 \mathrm{a}$ & $4.04 \mathrm{~b}$ \\
\hline $50 \mathrm{~Pb}+6 \mathrm{Se}$ & $155 \mathrm{a}$ & $3.09 \mathrm{c}$ \\
\hline
\end{tabular}

Values with different letters in the same column differ significantly from each other at $p<0.05$

$N D$ not detectable 1st pair of leaf blades, whereas intense staining was noted at the top of the 2 nd pair of leaves. The decrease in cell viability was visible in the $\mathrm{Pb}$-treated plants as an increase in the blue staining. The characteristic blue colour appeared over the entire surface of the leaf blades but stronger colouration was observed for the 2 nd pair of leaves. The addition of $\mathrm{Se}$ to the growth medium with $50 \mu \mathrm{M} \mathrm{Pb}$ decreased the staining intensity in the leaves. However, a lower Se concentration $(1.5 \mu \mathrm{M})$ under $\mathrm{Pb}$ treatment improved the viability of leaf blades more clearly, and the light blue staining was observed in the top part of the blades of the 1st pair of leaves, whereas small necrotic changes were observed mainly in the central part of the blades of the 2nd pair leaves. The higher Se concentration $(6 \mu \mathrm{M})$ was not so effective under $\mathrm{Pb}$ treatment. The leaf blades were characterized by the presence of light blue colour in the entire assimilatory parenchyma (Fig. 2).

\section{Analysis of the Oxidative Stress in the Shoots}

Histochemical analyses of $\mathrm{H}_{2} \mathrm{O}_{2}$ and $\mathrm{O}_{2}^{\bullet-}$ accumulation in the leaves were performed for visualization of the oxidative stress.

On day 14 , slight brown colouration indicating $\mathrm{H}_{2} \mathrm{O}_{2}$ production was observed only near the main vascular bundles in the basal part of all the control leaves. The exposition of the plants to $\mathrm{Pb}$ clearly intensified production of $\mathrm{H}_{2} \mathrm{O}_{2}$ in the leaf blades. A brown colour appeared in the vascular system, as well as in the assimilation parenchyma on the periphery of the leaf blades. In the $1.5 \mu \mathrm{M} \mathrm{Se}$ treated plants, only the vascular bundles were stained brown, but a stronger reaction was observed in the 1st pair leaf blades. In the $6 \mu \mathrm{M}$ Se-treated plants, the brown colour occurred mainly in the basal part of the leaf blades. However, in the $50 \mu \mathrm{M} \mathrm{Pb}+1.5 \mu \mathrm{M}$ Se-treated plants and the $50 \mu \mathrm{M} \mathrm{Pb}+6 \mu \mathrm{M}$ Se-treated plants, quite strong staining of leaf blades was observed, especially at the bottom of the 1st and 2nd pair leaves (Fig. 3).

A light blue colour indicating the formation of $\mathrm{O}_{2}^{\bullet-}$ appeared only near the main and the lateral vascular bundles of the control plant leaves. In the $50 \mu \mathrm{M} \mathrm{Pb}$-treated plants, significantly enhanced production of $\mathrm{O}_{2}^{\bullet-}$ was found, especially on the 1 st pair of leaves. On these leaf blades, an intense blue colour was present in nearly the entire surface of the leaf blades. On the 2 nd pair of leaves, strong blue colouration appeared in the some central parts of the leaf blades. The addition of Se to the growth medium with $\mathrm{Pb}$ decreased the staining resulting from formation of $\mathrm{O}_{2}^{\bullet-}$ in the $\mathrm{Pb}$-treated of leaves, both at lower and higher $\mathrm{Se}$ concentrations (Fig. 4).

The increase in the accumulation of reactive oxygen species enhanced production of lipid peroxides, which was an effect of oxidative stress. The level of MDA, one of the 
Table 2 The growth of shoots in Vicia faba L. minor plants cultivated for 14 days in the control solution or in the presence of $\mathrm{Pb}$ and/or Se

\begin{tabular}{lllllll}
\hline $\begin{array}{l}\mathrm{Pb} \text { and/or } \\
\begin{array}{l}\text { Se concentration } \\
(\mu \mathrm{M})\end{array}\end{array}$ & $\begin{array}{l}\text { Shoot } \\
\text { elongation } \\
(\mathrm{cm})\end{array}$ & $\begin{array}{l}\text { Shoot fresh } \\
\text { weight } \\
\left(\mathrm{mg} \mathrm{plant}^{-1}\right)\end{array}$ & $\begin{array}{l}\text { Shoot dry } \\
\text { weight } \\
\left(\mathrm{mg} \mathrm{plant}^{-1}\right)\end{array}$ & $\begin{array}{l}\text { Number } \\
\text { of leaves }\end{array}$ & $\begin{array}{l}\text { Length } \\
\text { of leaves } \\
(\mathrm{cm})\end{array}$ & $\begin{array}{l}\text { Width } \\
\text { of leaves } \\
(\mathrm{cm})\end{array}$ \\
\hline 0 & $10.44 \pm 1.03 \mathrm{a}$ & $2889.33 \pm 158.86 \mathrm{a}$ & $212.03 \pm 11.61 \mathrm{a}$ & $2.00 \pm 0.00 \mathrm{a}$ & $2.74 \pm 0.13 \mathrm{a}$ & $1.78 \pm 0.09 \mathrm{a}$ \\
$1.5 \mathrm{Se}$ & $13.23 \pm 0.62 \mathrm{a}$ & $2938.67 \pm 152.36 \mathrm{a}$ & $209.23 \pm 10.88 \mathrm{a}$ & $2.00 \pm 0.00 \mathrm{a}$ & $2.89 \pm 0.05 \mathrm{a}$ & $1.76 \pm 0.03 \mathrm{a}$ \\
$6 \mathrm{Se}$ & $11.73 \pm 1.17 \mathrm{a}$ & $2710.00 \pm 123.20 \mathrm{a}$ & $208.87 \pm 11.00 \mathrm{a}$ & $2.00 \pm 0.00 \mathrm{a}$ & $2.59 \pm 0.13 \mathrm{a}$ & $1.65 \pm 0.07 \mathrm{a}$ \\
$50 \mathrm{~Pb}$ & $13.07 \pm 0.52 \mathrm{a}$ & $2963.33 \pm 163.96 \mathrm{a}$ & $215.19 \pm 13.46 \mathrm{a}$ & $1.93 \pm 0.07 \mathrm{a}$ & $2.73 \pm 0.13 \mathrm{a}$ & $1.86 \pm 0.08 \mathrm{a}$ \\
$50 \mathrm{~Pb}+1.5 \mathrm{Se}$ & $13.49 \pm 0.90 \mathrm{a}$ & $2998.00 \pm 83.83 \mathrm{a}$ & $229.07 \pm 5.85 \mathrm{a}$ & $1.87 \pm 0.13 \mathrm{a}$ & $2.76 \pm 0.16 \mathrm{a}$ & $1.67 \pm 0.09 \mathrm{a}$ \\
$50 \mathrm{~Pb}+6 \mathrm{Se}$ & $11.47 \pm 0.52 \mathrm{a}$ & $3064.67 \pm 195.87 \mathrm{a}$ & $241.84 \pm 17.35 \mathrm{a}$ & $2.00 \pm 0.00 \mathrm{a}$ & $2.89 \pm 0.09 \mathrm{a}$ & $1.82 \pm 0.07 \mathrm{a}$ \\
\hline
\end{tabular}

Values are mean $\pm \operatorname{SE}(n=15)$. Values with different letters in the same column differ significantly from each other at $p<0.05$

Table 3 Chlorophyll and carotenoids contents in Vicia faba L. minor leaves grown for 14 days in the control solution or in the presence of $\mathrm{Pb}$ and/or Se

\begin{tabular}{llllll}
\hline $\begin{array}{l}\mathrm{Pb} \text { and/or Se } \\
\text { concentration }(\mu \mathrm{M})\end{array}$ & $\begin{array}{l}\mathrm{Chl} a \\
\left(\mathrm{mg} \mathrm{g}^{-1} \mathrm{FW}\right)\end{array}$ & $\begin{array}{l}\mathrm{Chl} \mathrm{Ch} \\
\left(\mathrm{mg} \mathrm{g}^{-1} \mathrm{FW}\right)\end{array}$ & $\begin{array}{l}\mathrm{Chl} a+b \\
\left(\mathrm{mg} \mathrm{g}^{-1} \mathrm{FW}\right)\end{array}$ & $\begin{array}{l}\mathrm{R}^{a} / b \\
\left(\mathrm{mg} \mathrm{g}^{-1} \mathrm{FW}^{2}\right.\end{array}$ & $\begin{array}{l}C a r \\
(\mathrm{mg} \mathrm{g}\end{array}$ \\
\hline 0 & $1.06 \mathrm{a}$ & $0.73 \pm 0.01 \mathrm{a}$ & $1.87 \pm 0.01 \mathrm{a}$ & $1.45 \pm 0.01 \mathrm{a}$ & $0.46 \pm 0.00 \mathrm{a}$ \\
$1.5 \mathrm{Se}$ & $1.04 \mathrm{~b}$ & $0.93 \pm 0.06 \mathrm{bc}$ & $2.08 \pm 0.08 \mathrm{bc}$ & $1.19 \pm 0.10 \mathrm{~b}$ & $0.51 \pm 0.02 \mathrm{~b}$ \\
$6 \mathrm{Se}$ & $1.05 \mathrm{ab}$ & $0.92 \pm 0.02 \mathrm{bc}$ & $2.09 \pm 0.02 \mathrm{bc}$ & $1.14 \pm 0.02 \mathrm{bc}$ & $0.51 \pm 0.01 \mathrm{bc}$ \\
$50 \mathrm{~Pb}$ & $1.06 \mathrm{a}$ & $0.88 \pm 0.01 \mathrm{~b}$ & $2.05 \pm 0.02 \mathrm{~b}$ & $1.20 \pm 0.02 \mathrm{~b}$ & $0.51 \pm 0.00 \mathrm{~b}$ \\
$50 \mathrm{~Pb}+1.5 \mathrm{Se}$ & $1.04 \mathrm{~b}$ & $1.04 \pm 0.01 \mathrm{c}$ & $2.21 \pm 0.01 \mathrm{c}$ & $1.00 \pm 0.01 \mathrm{c}$ & $0.55 \pm 0.00 \mathrm{c}$ \\
$50 \mathrm{~Pb}+6 \mathrm{Se}$ & $1.05 \mathrm{ab}$ & $0.89 \pm 0.01 \mathrm{~b}$ & $2.06 \pm 0.02 \mathrm{~b}$ & $1.19 \pm 0.02 \mathrm{bc}$ & $0.51 \pm 0.00 \mathrm{bc}$ \\
\hline
\end{tabular}

Values are mean $\pm \mathrm{SE}(n=15)$. Values with different letters in the same column differ significantly from each other at $p<0.05$

major lipid peroxidation indicators, increased in the $50 \mu \mathrm{M}$ $\mathrm{Pb}$-treated shoots by $47 \%$ in comparison to the control. Moreover, Se increased lipid peroxidation by 20 and $21 \%$ at $1.5 \mu \mathrm{M}$ Se and $6 \mu \mathrm{M} \mathrm{Se}$, respectively. The lower $(1.5 \mu \mathrm{M})$ Se concentration did not exert an effect on the MDA level in the $50 \mu \mathrm{M}$ Pb-treated shoots, but the higher $(6 \mu \mathrm{M})$ Se concentration decreased the MDA level by $22 \%$ in comparison to the plants treated with $\mathrm{Pb}$ (Fig. 5).

The T-SH content significantly increased, except for the Pb-treated plants. In the 1.5 and $6 \mu \mathrm{M}$ Se-treated plants, the T-SH content increased by 32 and $96 \%$, respectively. In the shoots treated with $50 \mu \mathrm{M} \mathrm{Pb}+1.5 \mu \mathrm{M}$ Se and $50 \mu \mathrm{M}$ $\mathrm{Pb}+6 \mu \mathrm{M}$ Se, the T-SH content increased by 129 and $93 \%$, respectively. The addition of 1.5 and $6 \mu \mathrm{M}$ Se to the growth medium with $\mathrm{Pb}$ intensified synthesis of thiol compounds in the shoots by 42 and $35 \%$, respectively, in comparison to the $50 \mu \mathrm{M} \mathrm{Pb}$-treated plants (Fig. 6).

In comparison to the control, a 3-fold increase in CAT activity in the shoots exposed to $50 \mu \mathrm{M} \mathrm{Pb}$ was observed. Se at the concentrations of 1.5 and $6 \mu \mathrm{M}$ increased CAT activity in the shoots by 74 and $103 \%$, respectively. The simultaneous treatment with $\mathrm{Pb}$ and $6 \mu \mathrm{M}$ Se increased CAT activity (204\%) in comparison to the control. In the groups exposed to both $\mathrm{Pb}$ and $\mathrm{Se}, \mathrm{CAT}$ activity was significantly lower in comparison to the $50 \mu \mathrm{M}$ Pb-treated plants, that is, 68 and $23 \%$ at $1.5 \mu \mathrm{M}$ Se and $6 \mu \mathrm{M}$ Se, respectively (Fig. 7a).

GPOX activity in the shoots treated with $\mathrm{Pb}, \mathrm{Se}$, and $50 \mu \mathrm{M} \mathrm{Pb}+6 \mu \mathrm{M}$ Se increased by $22-32 \%$ in comparison to the control. However, $1.5 \mu \mathrm{M}$ Se supplementation of $\mathrm{Pb}$-containing growth medium reduced GPOX activity by $51 \%$, in comparison to the plants treated with $50 \mu \mathrm{M}$ $\mathrm{Pb}$, to a level that was significantly lower than in the control (Fig. 7b).

In the shoots exposed to $\mathrm{Pb}$ or 1.5 or $6 \mu \mathrm{M} \mathrm{Se}$, an increase in the GSH-Px activity by 72,93 , and $86 \%$, respectively, was noted in comparison to the control. The addition of $1.5 \mu \mathrm{M}$ Se to the growth medium with $\mathrm{Pb}$ maintained the GSH-Px activity at the control level, which was $40 \%$ lower than in the shoots exposed to the $\mathrm{Pb}$ alone. However, addition of $6 \mu \mathrm{M}$ Se to the growth medium with $\mathrm{Pb}$ increased the GSH-Px activity by $93 \%$ (Fig. 7c).

\section{Discussion}

Se is a known anticarcinogen and antioxidant compound, which recently is quite frequently supplied in fertilizers to improve its deficiency in soil or to enrich plants and food crops in Se, having ameliorating advantages in food 
Fig. 1 Localization of lead (after rhodizonic acid staining) in Vicia faba L. minor 1st (I) and 2nd (II) pair leaves after 14 days of cultivation in the control solution or in the presence of $\mathrm{Pb}$ and/or Se. Brown colour indicates lead deposits in leaf blades (Color figure online)
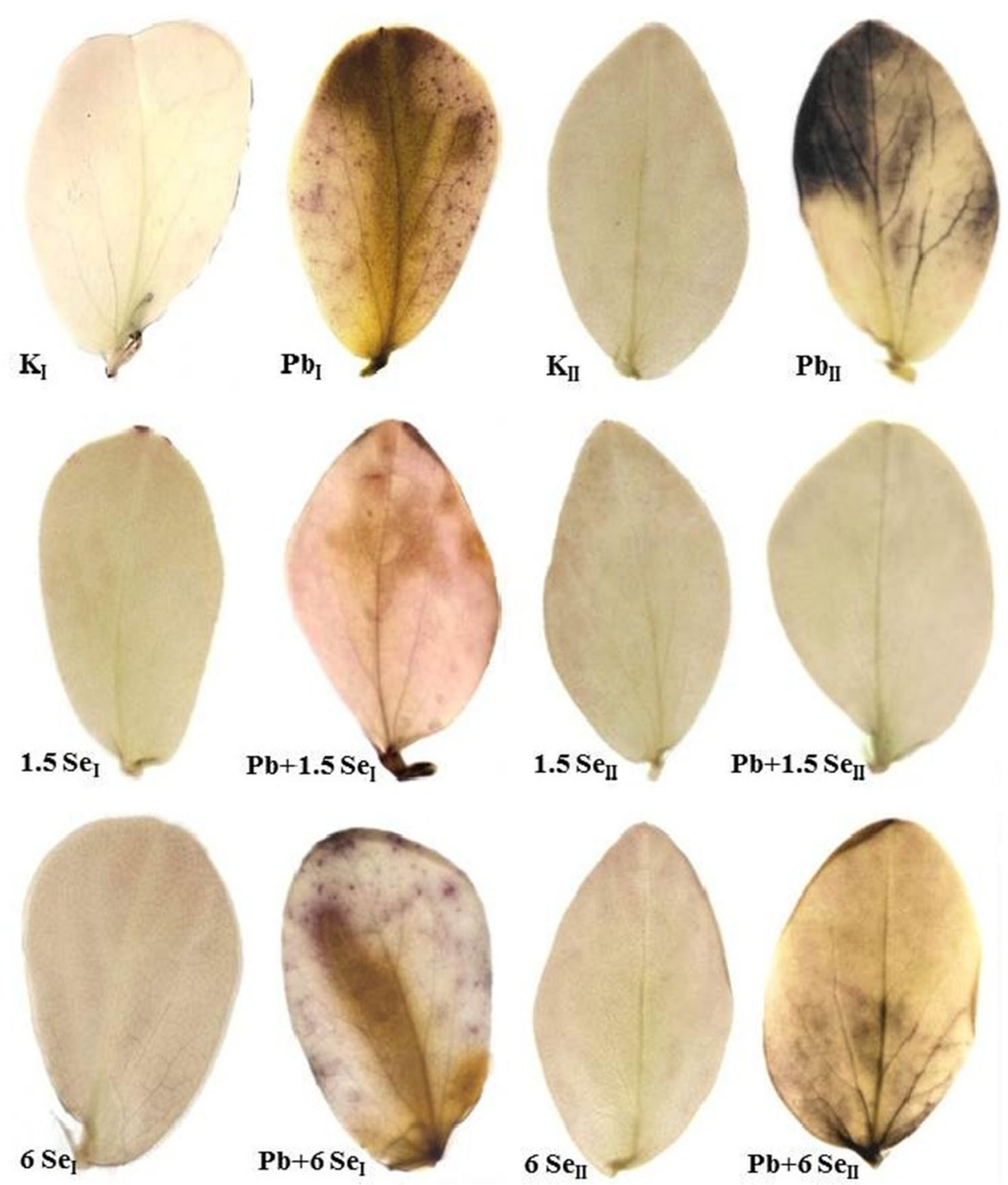

characteristics, like the shelf life (D'Amato and others 2014). The response of plants to $\mathrm{Se}$ under $\mathrm{Pb}$ exposure has been previously described by a few authors (Fargašová and others 2006; Mroczek-Zdyrska and Wójcik 2012); however, the literature in this field is quite limited and the results obtained are often contradictory, which relates to both the form and the dose of Se or the concentration ratios between the metal and Se applied (Fargašová and others 2006).

The uptake and accumulation of $\mathrm{Pb}$ by plants is an important and intensively studied problem. It has been proven that $\mathrm{Pb}$ is taken up from the growth medium and accumulated mainly in the roots (Garg and Aggarwal 2011; Mroczek-Zdyrska and Wójcik 2012). Consequently, shoots contain significantly less Pb (Garg and Aggarwal 2011; Sengar and others 2008; Wierzbicka and Potocka 2002). The rhodizonic method used in this study confirmed the presence of $\mathrm{Pb}$ mainly in the vascular bundles and in the mesophyll cells of the leaf blades similarly to the results obtained by Książek and others (1984).

The literature confirms the dose- and form of Se-dependent (selenate, selenite, and organic compounds, SeCys and SeMet) Se root/shoot accumulation (Simojoki and others 2003; Terry and others 2000). Selenite showed approximately $50 \%$ less accumulation of $\mathrm{Se}$ in the aboveground parts in comparison with selenate (Klusonova and others 2015; Zhang and others 2007). On the contrary, Lehotai and others (2012) found that selenite-treated plants accumulated more Se in their shoots. One likely explanation of this phenomenon can be that the oxidation process of selenite to selenate may appear during cultivation. However, both Se forms (selenate and selenite) are reduced to selenide, and next they run a common pathway in $\mathrm{Se}$ metabolism (Lehotai and others 2012). Moreover, in lower 
Fig. 2 Cell death (after trypan blue staining) of Vicia faba L. minor 1st (I) and 2nd (II) pair leaves after 14 days of cultivation in the control solution or in the presence of $\mathrm{Pb}$ and/or Se. Blue colour indicates sites of necrosis (Color figure online)
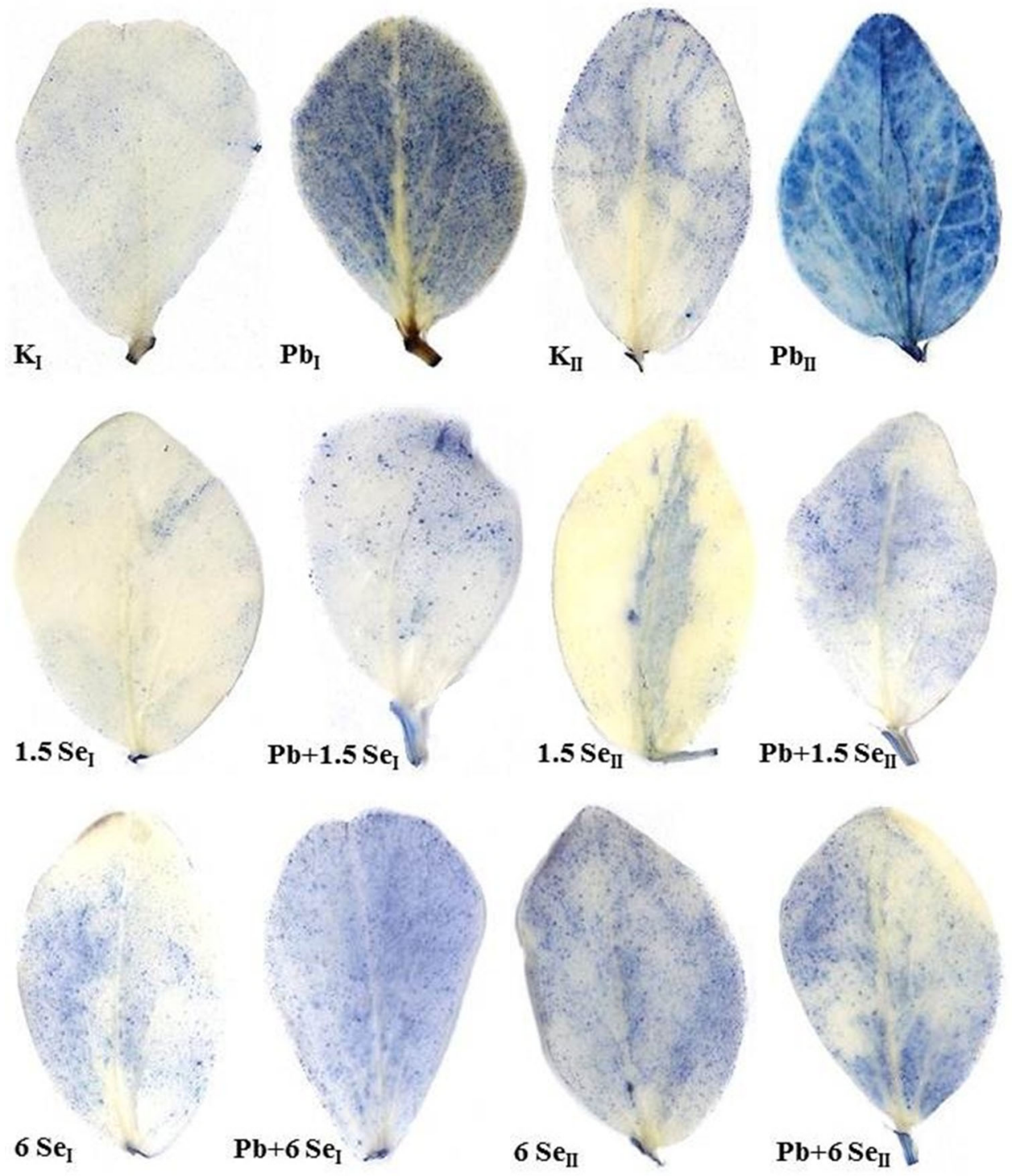

doses, Se was accumulated mainly in the roots, but at higher doses, its content in the roots and shoots was similar (Simojoki and others 2003). Similar to our results for Vicia faba L. minor, Se applied in the form of selenite is poorly translocated to shoots (De Souza and others 1998) because the majority remains in roots, where it is rapidly transformed into organic Se compounds (Fargašová and others 2006; Mroczek-Zdyrska and Wójcik 2012; Simojoki and others 2003; Terry and others 2000). Furthermore, Se-accumulator plants accumulate selenate in older leaves, whilst organic Se compounds (MeSeCys) are stored in the youngest tissues (Terry and others 2000). However, nonSe-accumulators store Se mainly in roots and only small amounts are located into the stem and leaves (Sors and others 2005).

Se can modify the uptake and accumulation of other elements that are important for plant metabolism. He and others (2004) found that the uptake of Fe by lettuce was enhanced after Se application. Furthermore, rice grains from seleniferous soil showed significantly higher concentrations of $\mathrm{As}, \mathrm{Cr}$, and $\mathrm{K}$ and lower concentrations of $\mathrm{S}$ and $\mathrm{Zn}$ in comparison to rice grown on normal soil (Sharma and others 2014).

Our research proved no Se effect on $\mathrm{Pb}$ content in the shoots of Vicia faba L. minor. The literature provides reports about various reduction levels in heavy metal $(\mathrm{Pb}$, $\mathrm{Cd}, \mathrm{Cr}, \mathrm{Co}, \mathrm{Ni}, \mathrm{Zn}$ ) uptake and accumulation in both the roots and the shoots of plants resulting from the presence of Se in a growth medium (Fargašová and others 2006). This difference could be a result of plant species, age, the part of the plant (leaves or shoots), and the mode of supplementation. Moreover, the effect of Se on heavy metal accumulation in plants depends strongly on the proportion between the elements (Fargašová and others 2006). In a 
Fig. 3 Visualization of hydrogen peroxide accumulation (after DAB staining) in Vicia faba L. minor 1 st (I) and 2nd (II) pair leaves after 14 days of cultivation in the control solution or in the presence of $\mathrm{Pb}$ and/or $\mathrm{Se}$
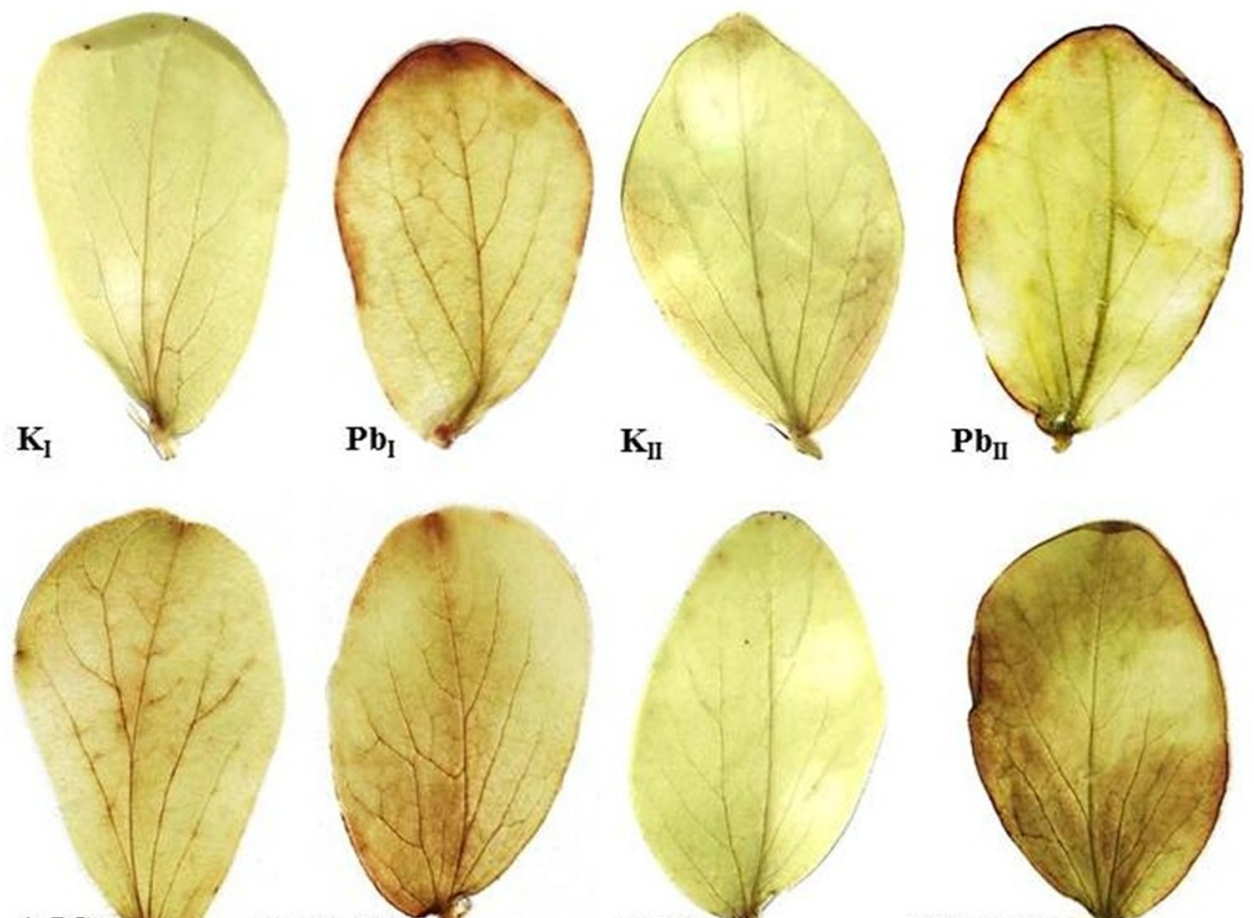

$1.5 \mathrm{Se}_{\mathrm{I}}$

$\mathrm{Pb}+1.5 \mathrm{Se}_{\mathrm{I}}$

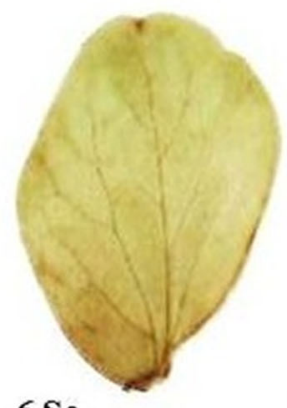

$6 \mathrm{Se}_{\mathrm{I}}$

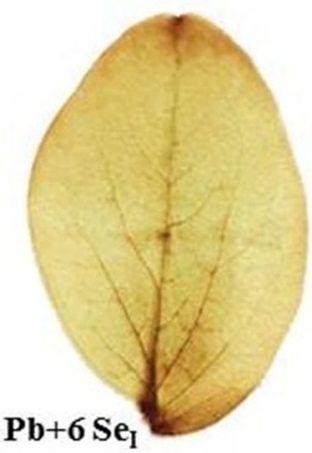

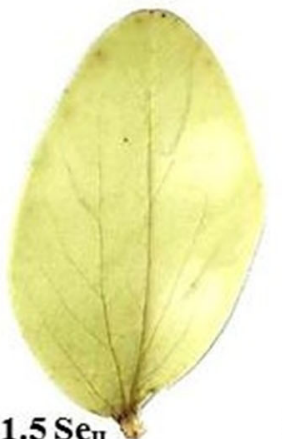

$1.5 \mathrm{Se}_{\text {II }}$

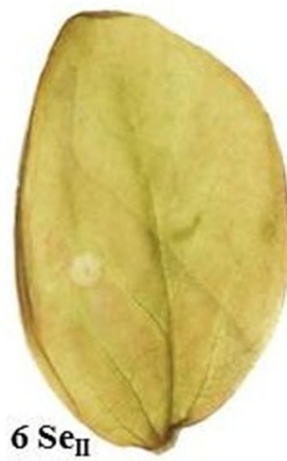

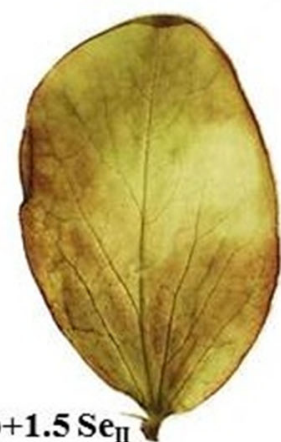

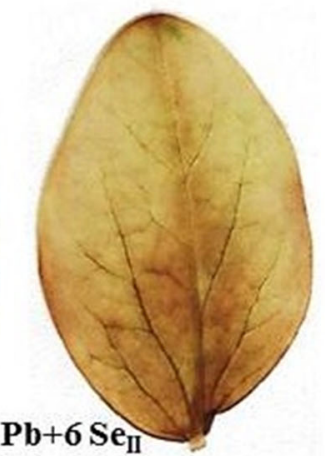

field experiment, the addition of selenite to lettuce subjected to $\mathrm{Pb}$ and $\mathrm{Cd}$ significantly decreased the accumulation of these heavy metals (He and others 2004). Similarly, Shanker and others (1996) noted that Se supplementation (both as selenite or selenate) to soil contaminated with $\mathrm{Cd}$ decreased the uptake and accumulation of $\mathrm{Cd}$ in maize; however, the decline in the $\mathrm{Cd}$ concentration under $\mathrm{Se}$ supplementation was greater in roots than in shoots. The mechanism of heavy metal detoxification by Se might be connected with inhibition of uptake and translocation of heavy metals from roots to shoots and/or formation of nontoxic Se-metal complexes (Feng and others 2013a). Belzile and others (2006) suggested that the mutual detoxification between selenite and $\mathrm{Hg}$ might be associated with formation of Se-Hg complexes. Interestingly, at higher Se concentrations, stimulation of heavy metal uptake can also be expected (Fargašová and others 2006; Feng and others 2013a). It was noted that selenite application stimulated the accumulation of As in Thunbergia alata (Bluemlein and others 2009), $\mathrm{Al}$ in ryegrass (Cartes and others 2010), or Cd and $\mathrm{Cu}$ in wheat and pea (Landberg and Greger 1994). It is assumed that these phenomena can be attributed to an improper dose of Se and/or abnormal S assimilation (Feng and others 2013a).

$\mathrm{The} \mathrm{Pb}$ dose used in this study had no negative effect on the growth parameters of Se-supplemented and non-Sesupplemented Vicia faba L. minor plants probably because a predominant amount of $\mathrm{Pb}$ was detected in roots (Mroczek-Zdyrska and Wójcik 2012). Such a restricted translocation of $\mathrm{Pb}$ from roots to shoots could be explained by effective protection of the photosynthetic apparatus (Vassilev and others 1995) or increased antioxidant defence in shoots (Verma and Dubey 2003). Our results are in agreement with others (Hawrylak-Nowak and others 2014), who reported that under Cd-stress there were no significant differences in the shoot biomass of Se-supplied 
Fig. 4 Visualization of superoxide anion accumulation (after NBT staining) in Vicia faba L. minor 1st (I) and 2nd (II) pair leaves after 14 days of cultivation in the control solution or in the presence of $\mathrm{Pb}$ and/or Se
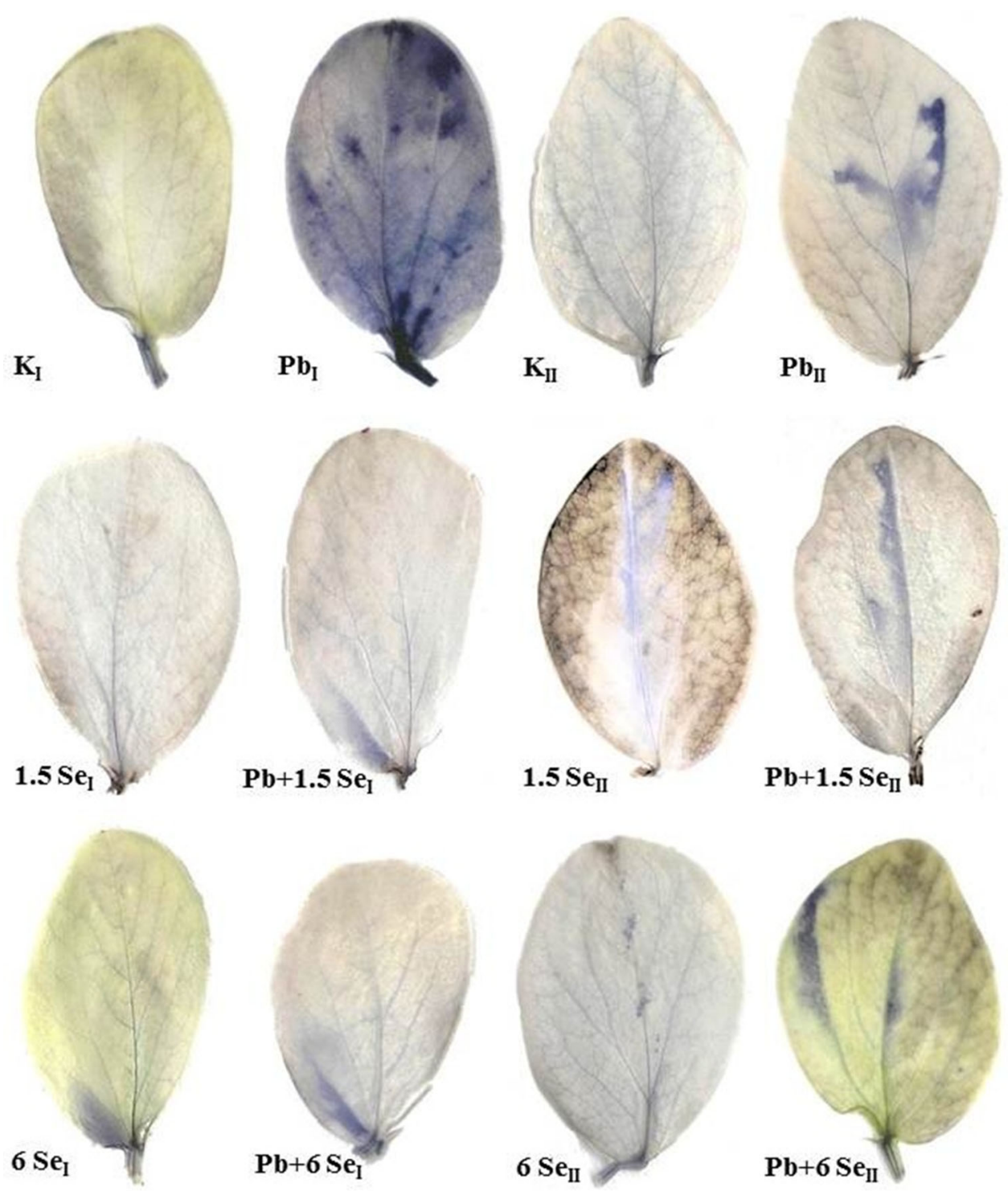

plants, compared to Cd-exposed plants. It is noteworthy that plant growth and biomass stimulation by sublethal doses of toxicants has been reported (Jia and others 2012) and this phenomenon is referred to as hormesis (KovácsBogdán and others 2010).

In the present study, there was no significant effect of Se on shoot growth and development, like in other research (Simojoki and others 2003; Xue and others 2001). However, literature data show ambiguous results from induction of shoot growth (Djanaguiraman and others 2005) to inhibition (Xue and others 2001). Trace amounts of Se stimulated growth in a variety of non-hyperaccumulators including ryegrass, lettuce, potato, and duckweed (PilonSmits and others 2009). Peng and others (2000) noted that low selenite doses induced the development of hydroponically grown wheat, whereas $\mathrm{Se}$ excess inhibited plant growth in a non-linear dose-response relationship.
Although most publications reported a decrease in the assimilation pigment content in the presence of heavy metals (Hawrylak and others 2007), an increase was also observed both under metal treatment (Jia and others 2012) and at a lower Se dose $(5 \mu \mathrm{M})$ in lettuce leaves (Hawrylak and others 2007) and in olive oil from Se-treated trees (D'Amato and others 2014), which is in accordance with our results. The increase in the assimilation pigment content can be explained by the low activity of chlorophyllase (Gupta and others 2012), the Se role in chlorophyll biosynthesis (Hawrylak and others 2007), protection of photosynthesis against light stress (Seppänen and others 2003), and the efficient removal of ROS by Se-stimulated SOD and GSH-Px (Djanaguiraman and others 2005). It is noteworthy that low-dose stressors increased photosynthetic activity, chl-protein complexes, and chl content, and the mechanism of the stimulation has been characterized in 


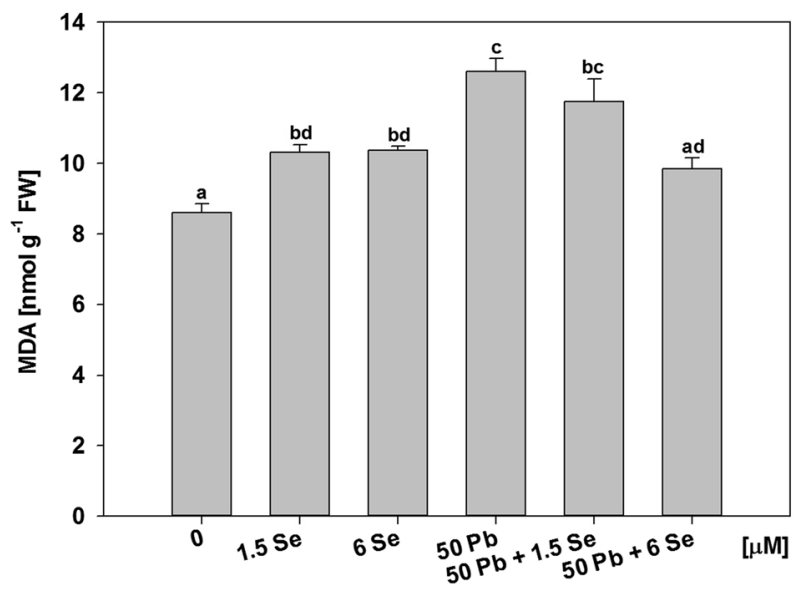

Fig. 5 The level of lipid peroxidation expressed in terms of the MDA concentration in the shoots of Vicia faba L. minor plants after 14 days of cultivation in the control solution or in the presence of $\mathrm{Pb}$ and/or Se. The bars indicate mean $(n=9) \pm$ SE. Values with different letters differ significantly from each other at $p<0.05$

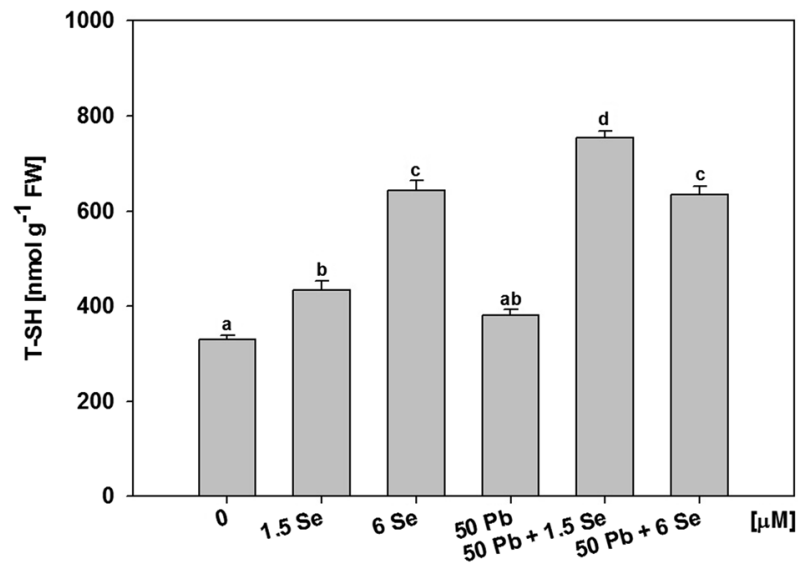

Fig. 6 The total SH content (T-SH) in the shoots of Vicia faba L. minor plants after 14 days of cultivation in the control solution or in the presence of $\mathrm{Pb}$ and/or Se. The bars indicate mean $(n=9) \pm \mathrm{SE}$. Values with different letters differ significantly from each other at $p<0.05$

terms of signalling pathways activated via induction of cytokinin synthesis (Kovács-Bogdán and others 2010). In our experiments, $\mathrm{Pb}$ stress and/or Se presence also intensified the synthesis of car in bean plants analogically to the literature data (Rastgoo and Alemzadeh 2011). Carotenoids are non-enzymatic antioxidant pigments that protect chlorophyll, membrane, and the cell genetic composition against ROS by quenching of triplet chlorophyll, restricting peroxidation, and destruction of the chloroplast membrane (Rastgoo and Alemzadeh 2011).

Moreover, Kong and others (2005) suggest that exogenous $\mathrm{Se}$, in an appropriate dose, can promote the integrity of the membrane system and some cellular organelles (mitochondria, chloroplasts) in the leaf and root tissues.

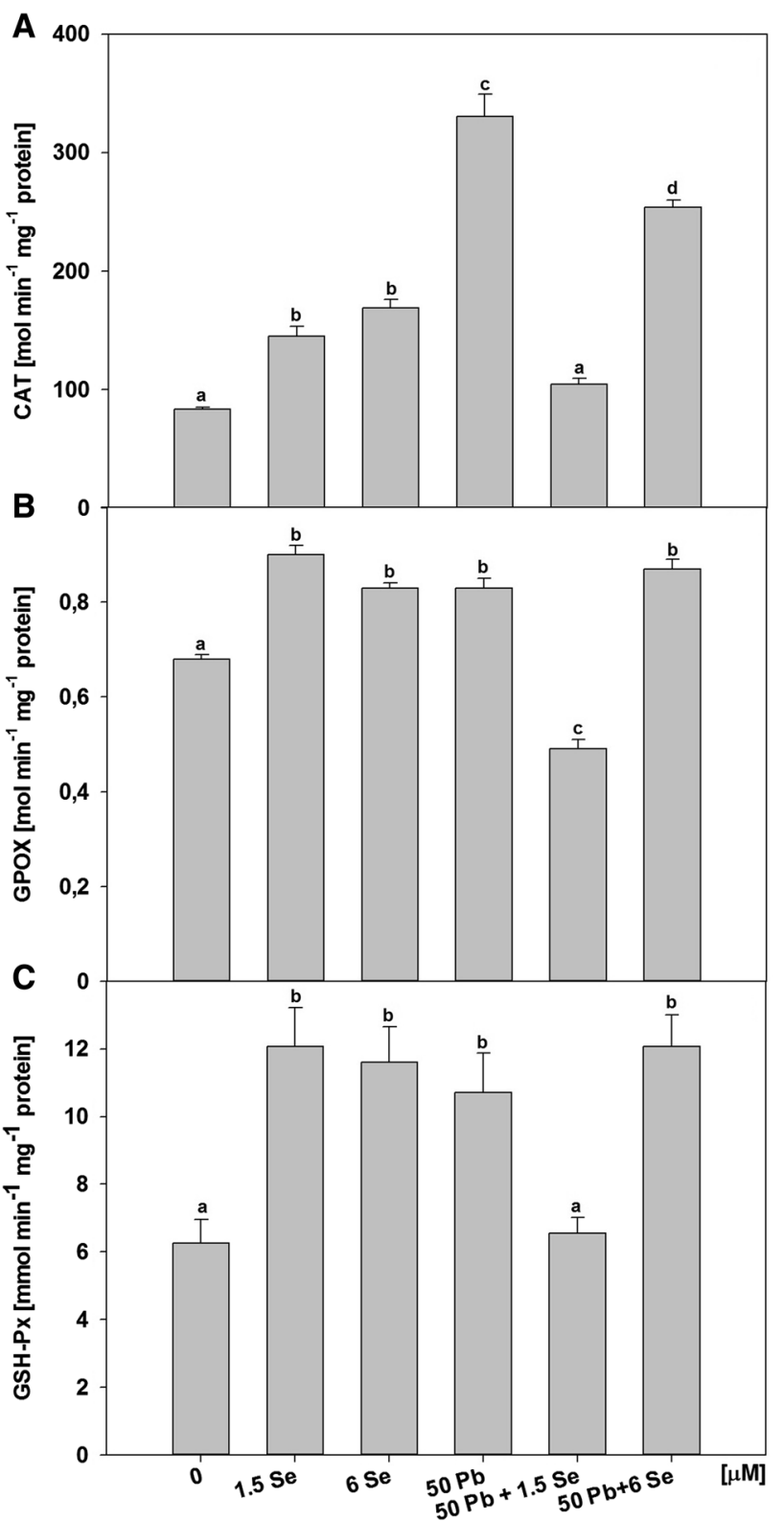

Fig. 7 Antioxidant enzyme activity ( $m o l m i n g$ protein) in the shoots of Vicia faba L. minor plants after 14 days of cultivation in the control solution or in the presence of $\mathrm{Pb}$ and/or Se. The bars indicate mean $(n=9) \pm$ SE. Values with different letters differ significantly from each other at $p<0.05$

In our experiment, we did not see characteristic symptoms of P deficiency, for example, decreased plant height, delayed leaf emergence, reduced tillering, secondary root development, dry matter yield (Grant and others 2001), appearance of a dark green colouration, or leaf malformation (Taiz and Zeiger 2002). This is in accordance with the statement that many plants can subsist on the reserves of P stores in the seed for about two (Grant and others 2001) or even several weeks (White and Veneklaas 2012). One exception could alternatively be necrotic spots on the 
leaves, which may be caused by short-term $\mathrm{P}$ deficiency (Taiz and Zeiger 2002), but we suggest that the local accumulation of $\mathrm{Pb}$ in the leaf tissues was the direct cause of cell death (Alkio and others 2005).

The cell membrane is an important barrier in preventing or reducing the metal entry into the cell. The excess of metals can influence plasma membrane integrity and cause disturbances in cell homeostasis (Benavides and others 2005). Thus, the injuries of the plasma membrane detected on the basis of MDA formation may serve as indicators of metal toxicity and lipid peroxidation and are usually connected with an increase in ROS production (Cheeseman 2007; Hanaka and others 2016). In this study, the significant increase in lipid peroxidation in the shoots under $\mathrm{Pb}$ treatment was accompanied by increased $\mathrm{H}_{2} \mathrm{O}_{2}$ and $\mathrm{O}_{2}^{\bullet-}$ production, as evidenced by the colour reaction with $\mathrm{DAB}$ and NBT in leaf blades. The elevation in ROS production in the shoots of abiotically stressed plants has often been described in the literature (Cheeseman 2007; Hanaka and others 2016; Rastgoo and Alemzadeh 2011; Velikova and others 2000) and may be associated with substantial damage caused by $\mathrm{Pb}$ stress and induction of cell death (KawaiYamada and others 2004). In the Vicia faba leaves, the areas of $\mathrm{Pb}$ accumulation were accompanied by increased necrotic symptoms. This overlap may suggest that the local accumulation of $\mathrm{Pb}$ in the leaf tissues was the direct cause of cell death (Alkio and others 2005).

In our experiment, the MDA level in the shoots was reduced in the presence of the higher Se concentrations introduced to the growth medium with $\mathrm{Pb}$. This indicates that the Se effect on the MDA level depends on the concentration applied, its content in the specific tissue, and the Se form. Consistent with our results, several researchers have also shown inhibition of lipid peroxide accumulation after Se supplementation in the form of selenite (HawrylakNowak and others 2014). These results can be attributed to the antioxidative properties of Se, especially in lower doses (Hartikainen and others 2000). However, for selenate, the lower Se concentrations decreased lipid peroxidation, whereas the higher Se concentration intensified it (Cartes and others 2005).

The presented data show that $\mathrm{Pb}$ stress leads to a significant (by $296 \%$ ) increase in CAT activity and suggest that this enzyme plays a fundamental role in the response to overproduction of ROS generated by $\mathrm{Pb}$ (Verma and Dubey 2003). Moreover, this metal also caused an increase in GPOX and GSH-Px activity (22 and $72 \%$, respectively) in the shoots of Vicia faba L. minor. The increase in the activity of the antioxidant enzymes in response to $\mathrm{Pb}$ is a common response of plants to stress (Rastgoo and Alemzadeh 2011; Verma and Dubey 2003).

The oxidoreductase enzymes (GSH-Px) are the most sensitive to $\mathrm{Se}$, due to the antioxidant properties of $\mathrm{Se}$
(Hartikainen and others 2000). In the present work, both Se concentrations significantly decreased CAT activity, but only the lower Se concentration significantly decreased GSH-Px and GPOX activity in the shoots exposed to Pb stress.

The use of Se as selenite in combination with $\mathrm{Pb}$ clearly intensified T-SH induction in the shoots of the examined bean plants, which is in accordance with other results (Hawrylak and Szymańska 2004). It seems that the differences in the T-SH group content between the roots and the shoots result from the rate of Se translocation to the shoots (Terry and others 2000).

In conclusion, our results indicate that addition of Se to $\mathrm{Pb}$-containing growth medium exerted a protective effect against $\mathrm{Pb}$ toxicity, and the different $\mathrm{Se}$ concentrations applied had a beneficial effect on different parameters (assimilation pigment content, T-SH and MDA content, antioxidant enzyme activity, or ROS production). The phenomenon of Se action on plants may be associated with reduced $\mathrm{Pb}$ accumulation in shoots and a positive effect of $\mathrm{Se}$ on necrotic changes in $\mathrm{Pb}$-exposed leaves. The mechanism of the beneficial effect of Se on antioxidant capacity may be direct, via the antioxidant activity of Se compounds, or indirect, via Se-induced upregulation of general stress resistance mechanisms (Pilon-Smits and others 2009). It is assumed that some oxygen radicals may be removed in a non-enzymatic way in the presence of $\mathrm{Se}$ (Hartikainen and others 2000). The beneficial influence of $\mathrm{Se}$ on $\mathrm{Pb}$-exposed shoots was related to an increase in the assimilation pigment concentration, which suggests that $\mathrm{Se}$ addition to a Pb-containing solution can help maintain the integrity of cell membranes in plastids (Hawrylak-Nowak and others 2014). Nevertheless, the effects described above show that different processes have different sensitivities to the presence of Se and its ambivalent character (protection or toxicity) results in beneficial or detrimental effects on plants. The influence of Se supplementation on $\mathrm{Pb}$-treated field bean shoots is dependent on the proportion of these elements in the nutrient solution and the positive effect of Se was more pronounced for the lower Se dose. It seemed that lack of $\mathrm{P}$ for 2 weeks did not significantly modify the plant response to $\mathrm{Se}$ and/or $\mathrm{Pb}$.

Open Access This article is distributed under the terms of the Creative Commons Attribution 4.0 International License (http://crea tivecommons.org/licenses/by/4.0/), which permits unrestricted use, distribution, and reproduction in any medium, provided you give appropriate credit to the original author(s) and the source, provide a link to the Creative Commons license, and indicate if changes were made.

\section{References}

Aebi H (1984) Catalase in vitro. Methods Enzymol 105:121-126. doi:10.1016/S0076-6879(84)05016-3 
Ali MB, Hahn EJ, Paek KY (2006) Copper-induced changes in the growth, oxidative metabolism and saponin production in suspension culture roots of Panax ginseng in bioreactors. Plant Cell Rep 25:1122-1132. doi:10.1007/s00299-006-0174-x

Alkio M, Tabuchi TM, Wang X, Colón-Carmona A (2005) Stress responses to polycyclic aromatic hydrocarbons in Arabidopsis include growth inhibition and hypersensitive response-like symptoms. J Exp Bot 56:2983-2994. doi:10.1093/jxb/eri295

Belenghi B, Acconcia F, Trovato M, Perazzolli M, Bocedi A, Polticelli F, Ascenzi P, Delledonne M (2003) AtCYS1, a cystatin from Arabidopsis thaliana, suppresses hypersensitive cell death. Eur J Biochem 270:2593-2604. doi:10.1046/j.1432-1033.2003. 03630.x

Belzile N, Wu GJ, Chen YM, Appanna VD (2006) Detoxification of selenite and mercury by reduction and mutual protection in the assimilation of both elements by Pseudomonas fluorescens. Sci Total Environ 367:704-714

Benavides MP, Gallego SM, Tomaro ML (2005) Cadmium toxicity in plants. Braz J Plant Physiol 17:21-34. doi:10.1590/S167704202005000100003

Bluemlein K, Klimm E, Raab A, Feldmann J (2009) Selenite enhances arsenate toxicity in Thunbergia alata. Environ Chem 6:486-494

Bradford MM (1976) A rapid and sensitive method for the quantitation of microgram quantities of protein utilizing the principle of protein-dye binding. Anal Biochem 72:248-254. doi:10.1016/0003-2697(76)90527-3

Cabañero AI, Madrid Y, Cámara C (2006) Selenium long-term administration and its effect on mercury toxicity. J Agric Food Chem 54:4461-4468. doi:10.1021/jf0603230

Cartes P, Gianfera L, Mora ML (2005) Uptake of selenium and its antioxidative activity in ryegrass when applied as selenate and selenite forms. Plant Soil 276:359-367

Cartes P, Jara AA, Pinilla L, Rosas A, Mora ML (2010) Selenium improves the antioxidant ability against aluminium-induced oxidative stress in ryegrass roots. Ann Appl Biol 156:297-307

Cheeseman JM (2007) Hydrogen peroxide and plant stress: a challenging relationship. Plant Stress 1:4-15

D'Amato R, Proietti P, Nasini L, Del Buono D, Tedeschini E, Businelli D (2014) Increase in the selenium content of extra virgin olive oil: quantitative and qualitative implications. Grasas Aceites 62:1-9

De Souza MP, Pilon-Smits EAH, Mel Lytle C, Hwang S, Tai J, Honma TSU, Yeh L, Terry N (1998) Rate-limiting steps in selenium assimilation and volatilization by Indian Mustard. Plant Physiol 117:1487-1494. doi:10.1104/pp.117.4.1487

Djanaguiraman M, Devi DD, Shanker AK, Sheeba A, Bangarusamy U (2005) Selenium - an antioxidative protectant in soybean during senescence. Plant Soil 272:77-86. doi:10.1007/s11104004-4039-1

Fargašová A, Pastierová J, Svetková K (2006) Effect of Se-metal pair combinations $(\mathrm{Cd}, \mathrm{Zn}, \mathrm{Cu}, \mathrm{Pb})$ on photosynthetic pigments production and metal accumulation in Sinapis alba L. seedlings. Plant Soil Environ 52:8-15

Feng R, Wei C, Tu S (2013a) The roles of selenium in protecting plants against abiotic stresses. Environ Exp Bot 87:58-68. doi:10.1016/j.envexpbot.2012.09.002

Feng R, Wei C, Tu S, Ding Y, Song Z (2013b) A dual role of Se on $\mathrm{Cd}$ toxicity: evidences from the uptake of $\mathrm{Cd}$ and some essential elements and the growth responses in paddy rice. Biol Trace Elem Res 151:113-121. doi:10.1007/s12011-012-9532-4

Garg N, Aggarwal N (2011) Effects of interactions between cadmium and lead on growth, nitrogen fixation, phytochelatin, and glutathione production in mycorrhizal Cajanus cajan (L.) Millsp. J Plant Growth Regul 30(3):286-300. doi:10.1007/s00344-0109191-7
Gnanasambandam A, Paull J, Torres A, Kaur S, Leonforte T, Li H, Zong X, Yang T, Materne M (2012) Impact of molecular technologies on faba bean (Vicia faba L.) breeding strategies. Agronomy 2:132-166. doi:10.3390/agronomy2030132

Grant CA, Flaten DN, Tomasiewicz DJ, Sheppard SC (2001) Importance of early season phosphorus nutrition. Better Crops 85:18-23. doi:10.4141/P00-093

Guo L, Lang M, Chandrasekar R, Liu G (2014) Advances in the study of genetic enrichment of selenium in plants. Clon Transgen 3:121

Gupta S, Gupta SM, Sane AP, Kumar N (2012) Chlorophyllase in Piper betle L. has a role in chlorophyll homeostasis and senescence dependent chlorophyll breakdown. Mol Biol Rep 39:7133-7142. doi:10.1007/s11033-012-1545-8

Hanaka A, Wójcik M, Dresler S, Mroczek-Zdyrska M, Maksymiec W (2016) Does methyl jasmonate modify the oxidative stress response in Phaseolus coccineus treated with $\mathrm{Cu}$ ? Ecotoxicol Environ Safe 124:480-488. doi:10.1016/j.ecoenv.2015.11.024

Hartikainen H, Xue T (2000) The promotive effect of selenium on plant growth as triggered by ultraviolet irradiation. J Environ Qual 28:1372-1375. doi:10.2134/jeq1999.004724250028 $00040043 x$

Hartikainen H, Xue T, Piironen V (2000) Selenium as an anti-oxidant and pro-oxidant in ryegrass. Plant Soil 225:193-200

Hawrylak B, Szymańska M (2004) Selenium as a suphydrylic group inductor in plants. Cell Mol Biol Lett 9:329-336

Hawrylak B, Matraszek R, Szymańska M (2007) Response of lettuce (Lactuca sativa $\mathrm{L}$.) to selenium in nutrient solution contaminated with nickel. VCRB 67:63-70. doi:10.2478/v10032-007-0031-7

Hawrylak-Nowak B, Dresler S, Wójcik M (2014) Selenium affects physiological parameters and phytochelatins accumulation in cucumber (Cucumis sativus L.) plants grown under cadmium exposure. Sci Hortic 172:10-18. doi:10.1016/j.scienta.2014.03. 040

He PP, Lv XZ, Wang GY (2004) Effects of Se and Zn supplementation on the antagonism against $\mathrm{Pb}$ and $\mathrm{Cd}$ in vegetables. Environ Int 30:167-172

Heath RL, Packer L (1968) Photoperoxidation in isolated chloroplasts: I. Kinetics and stoichiometry of fatty acid peroxidation. Arch Biochem Biophys 125:189-198. doi:10.1016/00039861(68)90654-1

Hoagland DR, Arnon DJ (1959) The water-culture method of growing plants without soil. Calif Agric Exp Stn Circ 347:26-29

Jia L, Liu Z, Chen W, He X (2012) Stimulative effect induced by lowconcentration cadmium in Lonicera japonica Thunb. Afr $\mathrm{J}$ Microbiol Res 6:826-833

Kawai-Yamada M, Ohori Y, Uchimiya H (2004) Dissection of Arabidopsis Bax inhibitor-1 suppressing Bax-, hydrogen peroxide-, and salicylic acid-induced cell death. Plant Cell 16:21-32. doi: $10.1105 /$ tpc.014613

Klusonova I, Horky P, Skladanka J, Kominkova M, Hynek D, Zitka O, Skarpa P, Kizek R, Adam V (2015) An effect of various selenium forms and doses on antioxidant pathways at clover (Trifolium pratense L.). Int J Electrochem Sci 10:9975-9987

Kong L, Wang M, Bi D (2005) Selenium modulates the activities of antioxidant enzymes, osmotic homeostasis and promotes the growth of sorrel seedlings under salt stress. Plant Growth Reg 45:155-163. doi:10.1007/s10725-005-1893-7

Kovács-Bogdán E, Nyitrai P, Keresztes Á (2010) How does a little stress stimulate a plant? Plant Signal Behav 5:354-358

Książek M, Woźny A, Siwecki R (1984) The sensitivity of poplar leaves to lead nitrate and the intracellular localization of lead. Eur J Forest Pathol 14:113-122

Landberg T, Greger M (1994) Influence of selenium on uptake and toxicity of copper and cadmium in pea (Pisum sativum) and wheat (Triticum aestivum). Physiol Plant 90:637-644 
Lehotai N, Kolbert Z, Pető A, Feigl G, Ördög A, Kumar D, Tari I, Erdei L (2012) Selenite-induced hormonal and signalling mechanisms during root growth of Arabidopsis thaliana $\mathrm{L}$. J Exp Bot 63:5677-5687

Li HF, McGrath SP, Zhao FJ (2008) Selenium uptake, translocation and speciation in wheat supplied with selenate or selenite. New Phytol 178:92-102

Lichtenthaler HK, Wellburn AR (1983) Determinations of total carotenoids and chlorophylls a and $\mathrm{b}$ of leaf extracts in different solvents. Biochem Soc Trans 603:591-592

Lyons GH, Genc Y, Soole K, Stangoulis JCR, Liu F, Graham RD (2009) Selenium increases seed production in Brassica. Plant Soil 318:73-80

Maas FM, de Kok LJ, Peters JL, Kuiper PJC (1987) A comparative study on the effects of $\mathrm{H}_{2} \mathrm{~S}$ and $\mathrm{SO}_{2}$ fumigation on the growth and accumulation of sulfate and sulfhydryl compounds in Trifolium pretense L., Glycine max Merr. and Phaseolus vulgaris L. J Exp Bot 38:1459-1469

Mroczek-Zdyrska M, Wójcik M (2012) The influence of selenium on root growth and oxidative stress induced by lead in Vicia faba $\mathrm{L}$. minor plants. Biol Trace Elem Res 147:320-328. doi:10.1007/ s12011-011-9292-6

Peng A, Xu Y, Liu JH, Wang ZJ (2000) Study on the dose-effect relationship of selenite with the growth of wheat. Biol Trace Elem Res 76:175-181

Pilon-Smits EAH, Quinn CF, Tapken W, Malagoli M, Schiavon M (2009) Physiological functions of beneficial elements. Curr Opin Plant Biol 12:267-274

Rastgoo L, Alemzadeh A (2011) Biochemical responses of Gouan (Aeluropus littoralis) to heavy metals stress. AJCS 5:375-383

Sengar RS, Gautam M, Sengar RS, Garg SK, Sengar K, Chaudhary R (2008) Lead stress effects on physiobiochemical activities of higher plants. Rev Environ Contam Toxicol 196:73-93. doi:10. 1007/978-0-387-78444-1_3

Seppänen M, Turakainen M, Hartikainen H (2003) Selenium effects on oxidative stress in potato. Plant Sci 165:311-319

Shanker K, Mishra S, Srivastava S, Srivastava R, Dass S, Prakash S, Srivastava MM (1996) Effect of selenite and selenate on plant uptake of cadmium by maize (Zea mays). Bull Environ Contam Toxicol 56:419-424

Sharma S, Goyal R, Sadana US (2014) Selenium accumulation and antioxidant status of rice plants grown on seleniferous soil from northwestern India. Rice Sci 21:327-334

Shinogi T, Suzuki T, Kurihara T, Narusaka Y, Park P (2003) Microscopic detection of reactive oxygen species generation in the compatible and incompatible interactions of Alternaria alternata Japanese pear pathotype and host plants. J Gen Plant Pathol 69:7-16. doi:10.1007/s10327-002-0013-z

Simojoki A, Xue T, Lukkari K, Pennanen A, Hartikainen H (2003) Allocation of added selenium in lettuce and its impact on roots. Agric Food Sci Finl 12:55-164
Singh AK, Bhatt BP, Upadhyaya A, Kumar S, Sundaram PK, Singh BK, Chandra N, Bharati RC (2012) Improvement of faba bean (Vicia faba L.) yield and quality through biotechnological approach: a review. Afr J Biotechnol 11:15264-15271

Sors TG, Ellis DR, Salt DE (2005) Selenium uptake, translocation, assimilation and metabolic fate in plants. Photosynth Res 86:373-389

Taiz L, Zeiger E (2002) Plant Physiology, 3rd edn. Sinauer Associates, Sunderland, pp 72-73

Terry N, Zayed M, de Souza MP, Tarun AS (2000) Selenium in higher plants. Annu Rev Plant Physiol Plant Mol Biol 51:401-432

Tóth G, Hermann T, Da Silva MR, Montanarella L (2016) Heavy metals in agricultural soils of the European Union with implications for food safety. Environ Int 88:299-309. doi:10. 1016/j.envint.2015.12.017

Vassilev A, Iordanov I, Chakalova E, Kerin V (1995) Effect of cadmium stress on growth and photosynthesis of young barley (H. vulgare L.) plants. 2. Structural and functional changes in photosynthetic apparatus. Bulg J Plant Physiol 21:12-21

Velikova V, Yordanov I, Edreva A (2000) Oxidative stress and some antioxidant systems in acid rain-treated bean plants. Protective role of exogenous polyamines. Plant Sci 151:59-66. doi:10. 1016/S0168-9452(99)00197-1

Verma S, Dubey RS (2003) Lead toxicity induces lipid peroxidation and alters the activities of antioxidant enzymes in growing rice plants. Plant Sci 164:645-655. doi:10.1016/S01689452(03)00022-0

Wang CQ, Xu HJ, Liu T (2011) Effect of selenium on ascorbateglutathione metabolism during PEG-induced water deficit in Trifolium repens L. J Plant Growth Regul 30(4):436-444

White P, Veneklaas E (2012) Nature and nurture: the importance of seed phosphorus content. Plant Soil 357:1-8. doi:10.1007/ s11104-012-1128-4

Wierzbicka M (1987) Lead translocation and localization in Allium cepa roots. Can J Bot 65:1851-1860

Wierzbicka M, Potocka A (2002) Lead tolerance in plants growing on dry and moist soil. Acta Biol Crac Bot 44:21-28

Winkel LHE, Vriens B, Jones GD, Schneider LS, Pilon-Smits E, Bañuelos GS (2015) Selenium cycling across soil-plant-atmosphere interfaces: a critical review. Nutrients 7:4199-4239

Xue T, Hartikainen H, Piironen V (2001) Antioxidative and growthpromoting effect of selenium in senescing lettuce. Plant Soil 27:55-61

Zhang P, Ryan JA (1999) Formation of chloropyromorphite from galena $(\mathrm{PbS})$ in the presence of hydroxyapatite. Environ Sci Technol 33:618-624. doi:10.1021/es980314a

Zhang L, Ackley AR, Pilon-Smits EAH (2007) Variation in selenium tolerance and accumulation among 19 Arabidopsis thaliana accessions. J Plant Physiol 164:327-336 